\title{
Energy Saving for GO Green Environment
}

\author{
B.Neeraja, Arti Chandani, N.Tarun Sastry, J.Saravanan
}

\begin{abstract}
Green environment is not only planting of trees. It need not always be to create or invent something new for having a green surroundings and neighborhood. It can also be to measure to be taken to save our neighborhood from pollution. Many of us do not know the impact of using halogen lamps, neon lamps and other high voltage generating lighting system on our environment.

These bulbs not only generate more heat in the surroundings where they are used but also consume high electricity. These lights when discarded will produce gases which are more harmful for the environment. They pollute the air by producing argon gas which will cause health issues like cancer, skin diseases. In the present day of nuclear families people are using more electricity and burn more lamps to have lighting in their homes. To give more clarity they are using artificial lighting to make their homes bright. This problem never arouse in the earlier period as the homes constructed were naturally built in such a way more air circulation was there and more ventilation. Homes in earlier days had backyards and more open space for good air circulation and natural lighting. But in the present few decades the culture of cluster homes apartments, multiplex complexes have become more common as people from rural areas are shifting towards urban cities. To accommodate these migrated families it has become a must to go for multiplex complexes and apartments. This is generating more pollution in the environment. In earlier days we never heard the terms of global warming, pollution control measures, Go green concepts. All these concepts have evolved in the last few decades. One of the reason is during increase in number of apartments, nuclear families. In places where one joint family was using a single lamp to complete their day to day activities are now replaced by 2 or 3 families using one light each in each house. So instead of one light we are using 3 or 4 lamps and generating more heat and pollution in our environment.
\end{abstract}

The present study is an attempt to find out the alternative solution of using $L E D / L C D$, iCaTS lamps on the energy saving and cost saving and environment friendly electric usage system

Keywords-Domestic Lighting, Residential Complexes, Residential Associations, \& Electricity Consumption

\section{INTRODUCTION}

Today, most of the cities in India consume $60-70 \%$ of the Total energy supply, a figure that will only increase over time. Looking forward, how these cities will manage to keep costs under control to meet the growing energy demand as 30 $-40 \%$ of it is utilization by the Lighting segments of the cities.

Revised Version Manuscript Received on July 18, 2019.

B.Neeraja, Professor and Deputy Head, Dr.MGR Educational and Research Institute, Maduravoyal, Chennai, India (E-Mail: neeraja.mba@drmgrdu.ac.in)

Arti Chandani, Associate Professor, Symbiosis Institute of Management Studies, Range Hills Road, Pune, Maharashtra, India. (E-Mail: arti.chandani@sims.edu)

N.Tarun Sastry, CSE IInd Year, Rajalakshmi Institute of Technology, Kuthambakkam, Chennai, India (E-Mail: tarunsastry.redmi@gmail.com)

J.Saravanan, CSE IInd Year, Rajalakshmi Institute of Technology, Kuthambakkam, Chennai, India( Email: saravanan.j.2017.cse@ritchennai.edu.in)
Table 1: Shows the present type of technology used for the domestic lighting systems in India

\begin{tabular}{|l|c|c|c|}
\hline \multicolumn{1}{|c|}{$\begin{array}{c}\text { Technology } \\
\text { Type }\end{array}$} & $\begin{array}{c}\text { Colour } \\
\text { Temperature }\end{array}$ & $\begin{array}{c}\text { Average } \\
\text { Efficacy } \\
\text { (lm/W) }\end{array}$ & $\begin{array}{c}\text { Lamp } \\
\text { Life } \\
\text { (hrs) }\end{array}$ \\
\hline Incandescent & $2500 \mathrm{k}-2700 \mathrm{k}$ & 14 & 2,000 \\
\hline $\begin{array}{l}\text { Mercury Vapor } \\
\text { (MV) }\end{array}$ & $4,100 \mathrm{~K}$ & 50 & $\begin{array}{c}14,000- \\
20,000\end{array}$ \\
\hline $\begin{array}{l}\text { Low Pressure } \\
\text { Sodium (LPS) }\end{array}$ & $1,800 \mathrm{~K}$ & 150 & 16,000 \\
\hline $\begin{array}{l}\text { High Pressure } \\
\text { Sodium (HPS) }\end{array}$ & $2,100 \mathrm{~K}$ & 90 & 24,000 \\
\hline $\begin{array}{l}\text { Metal Halide } \\
\text { (MH) }\end{array}$ & $2900 \mathrm{~K}-4000 \mathrm{~K}$ & 80 & $9,000-$ \\
\hline $\begin{array}{l}\text { T12 Linear } \\
\text { Fluorescent }\end{array}$ & $3,000 \mathrm{~K}-6500 \mathrm{~K}$ & 50 & 10,000 \\
\hline $\begin{array}{l}\text { T5 } \\
\text { Fluorescent }\end{array}$ & $2700 \mathrm{~K}-4000 \mathrm{~K}$ & 50 & 10,000 \\
\hline $\begin{array}{l}\text { Compact } \\
\text { Fluorescent } \\
\text { (CFL) }\end{array}$ & $2700 \mathrm{~K}-4000 \mathrm{~K}$ & 60 & 15,000 \\
\hline
\end{tabular}

As on date the day-today transactions such as switching on and switching off the loads is done manually by a person going to each control panel or it controlled by using the timer device. Further the energy usage data and status of glowing hours and health of lamps cannot be monitored and further analyzed by any type of reporting. Any Cluster of lamps cannot be stepped-down individually depending on traffic, Climatic conditions etc. The existing lighting infrastructure is not efficiently classified into manageable grids. The complete network of lighting is not digitized and hence the system cannot be used for better accessibility and functionality on each grid from remote location with a mouse click away by using Computer or PDA or from a GSM/ CDMA telephone device.

The alternative solutions for the present situation as follows:

1. Replacing the present lighting system with LED Blubs

2. Using other Alternative system such as iCaTS

iCaTS - intelligent Control and Tracking System is an intelligent system to control and monitor the energy consumption in various lighting sectors spread across the Country and Globe. It's a micro controller system, developed with focus on Energy conservation and Central Remote Controlling and Monitoring of the electrical activity at different locations. It not only controls and monitors the 
lights but also leads to 30 to $40 \%$ of direct energy saving's, and substantially reduces the maintenance cost. As it is already been utilized by Major City and Municipal Corporations for street lights across Andhra, Karnataka, and Telangana. It can be used by Developers and Private undertaking to reduce their Power expenses. It a means for saving the power considering the future in advance.

\section{NEED OF THE STUDY}

Today every organization is trying to participate in the process of reducing the carbon foot-prints in the world. With respect to lighting segment on this, the common perception is to replace the existing lightings with LED Bulbs. The LED Companies states that, if consumers use the LED Blub by replacing with the existing Bulbs, there could be a savings around $40-50 \%$ on the expenditure of electricity consumption or there can be a better alternative to this LED system.

Table 01: Details of the Present Lightings System.

\begin{tabular}{|c|l|c|c|c|c|c|c|}
\hline Sl/No & Common Area & Light Type & No's & Watts & kw/Hour & Hours & Units/Day \\
\hline 1 & Ground Floor Parking & T-5 & 20 & 36 & 0.79 & 5 & 3.96 \\
\hline 2 & Fazed (outdoor Focus) & HPSV/MH & 4 & 150 & 0.66 & 5 & 3.30 \\
\hline 3 & Stairs \& Common Area & T-5 & 15 & 36 & 0.59 & 12 & 7.13 \\
\hline 4 & Lift & T-5 & 4 & 18 & 0.08 & 24 & 1.90 \\
\hline & Amenities Area & & & & & & \\
\hline 1 & Entry Gates & Halogen/MH & 2 & 150 & 0.33 & 12 & 3.96 \\
\hline 2 & Visitors Parking & T-5 & 10 & 36 & 0.40 & 12 & 4.75 \\
\hline 3 & Swimming Pool & MH / SV & 12 & 35 & 0.46 & 5 & 2.31 \\
\hline 4 & Kids Play Area & Halogen/MH & 6 & 70 & 0.46 & 5 & 2.31 \\
\hline & & & & & & Total & $\mathbf{2 9 . 6 2}$ \\
\hline
\end{tabular}

Table 17: Details of the Present Lightings System in Common Area.

\begin{tabular}{|c|l|c|c|c|c|c|c|}
\hline Sl/No & \multicolumn{1}{|c|}{ Common Area } & Light Type & No's & Watts & kw/Hour & Hours & Units/Day \\
\hline 1 & Basement 1 Parking & T-5 & 140 & 36 & 5.04 & 24 & 120.96 \\
\hline 2 & Basement 2 Parking & T-5 & 140 & 36 & 5.04 & 24 & 120.96 \\
\hline 3 & Fazed (outdoor Focus) & HPSV/MH & 44 & 150 & 6.60 & 5 & 33.00 \\
\hline 4 & Stairs \& Common Area & T-5 & 90 & 36 & 3.24 & 12 & 38.88 \\
\hline 5 & Lift & T-5 & 8 & 18 & 0.14 & 24 & 3.46 \\
\hline & Amenities Area & & & & Total & $\mathbf{3 1 7}$ \\
\hline 1 & Entry Gates & Halogen/MH & 24 & 150 & 3.60 & 12 & 43.20 \\
\hline 2 & Visitors Parking & SV & 80 & 70 & 5.60 & 12 & 67.20 \\
\hline 3 & Drive Way & MH / SV & 200 & 70 & 14.00 & 12 & 168.00 \\
\hline 4 & Lawn Area & MH / SV & 120 & 35 & 4.20 & 5 & 21.00 \\
\hline 5 & Multi Propose Track & MH / SV & 150 & 35 & 5.25 & 5 & 26.25 \\
\hline 6 & Swimming Pool & MH / SV & 30 & 70 & 2.10 & 5 & 10.50 \\
\hline 7 & Basket Ball Court & Halogen/MH & 36 & 150 & 5.40 & 5 & 27.00 \\
\hline 8 & Cricket Pitch & Halogen/MH & 36 & 150 & 5.40 & 5 & 27.00 \\
\hline 9 & Tennis Court & Halogen/MH & 36 & 150 & 5.40 & 5 & 27.00 \\
\hline 10 & Open Theatre & Halogen/MH & 20 & 150 & 3.00 & 5 & 15.00 \\
\hline 11 & Party Lawn & MH / SV & 40 & 35 & 1.40 & 5 & 7.00 \\
\hline 12 & Club House Floor 1 & MH / SV & 50 & 70 & 3.50 & 5 & 17.50 \\
\hline 13 & Club House Floor 2 & MH / SV & 100 & 35 & 3.50 & 5 & 17.50 \\
\hline 14 & Kids Play Area & Halogen/MH & 50 & 70 & 3.50 & 5 & 17.50 \\
\hline 15 & Landscape Area & MH / SV & 50 & 70 & 3.50 & 5 & 17.50 \\
\hline & & & & & & Total & $\mathbf{5 0 9}$ \\
\hline
\end{tabular}


Feasible solution for replacing the present lighting system may be as follows:

The Complex must have Lighting Energy Efficient Management System which must be built in, in order to ensure the following:

1. Initiate's Go Green Concept - a Social \& Environmental initiative.

2. Cuts down Operating / Maintenance Cost up-to $40 \%$.

3. SMS - Services supports globally, which is user Friendly with remote access.

4. Robust Data Management along with accurate usage.

5. Effective Grid Control Management \& Scheduling with Critical alerts.

6. Mechanisms build into match with any types of present Lighting Devices / Systems.

7. Compactable with different types of Energy Power inputs.

8. Gives additional life span for the existing lighting devices.

9. Getting Carbon Credits for using the technology.

10. Excellent Returns on Investment.

\section{REFERENCES}

1. Lighting Brochure's and Price list of Various Lamps manufacturing companies in India.

2. iCaTS Brochure.

3. U.S. Department of Energy, Office of Energy Efficiency and Renewable Energy - LED Frequently Asked Questions.

4. U.S. Department of Energy, Office of Energy Efficiency and Renewable Energy - Establishing LED Equivalency.

5. U.S. Department of Energy, Office of Energy Efficiency and Renewable Energy - Energy Efficiency of LEDs.

6. U.S. Department of Energy, Office of Energy Efficiency and Renewable Energy - Lifetime and Reliability.

7. Venture's Efficient Lighting Systems Technical Brief - Lifetime and Reliability comparisons. 